\title{
STUDIES ON WATER USE EFFICIENCY OF GRAFTED AND NON-GRAFTED MELON PLANTS GROWN UNDER TWO SOILLESS CULTURE SYSTEMS
}

\author{
MONA M. ABD EL-WANIS ${ }^{1}$, M.M.H. ABDEL-BAKY ${ }^{2}$ and \\ S.R. SALMAN ${ }^{2}$
}

\author{
1. Protected Cultivation Dept., Horticulture Research Institute, Agriculture \\ Research center \\ 2. Vegtable. Research Dept., National Research Center, Cairo, Egypt
}

(Manuscript received 24 April 2018)

\begin{abstract}
$\mathrm{H}$ ydroponic culture is the fastest growing sector of agriculture, and it could be impetus for food production in the future. It is expected to grow exponentially also in the future, as conditions of growing soil becoming difficult. In the current study, the effect of different rootstocks on cantaloupe plants (Cucumis melo L.) F1 hybrid Galia and the reflection of that on water consumption, growth, nutrient uptake, fruit yield and quality were studied for two successive seasons 2016 and 2017 by comparing grafted plants with non-grafted ones under two systems of hydroponic (Nutrient Film Technique and substrate culture mixture of 1 peat, 1 vermiculite and 1 perlite). The Galia cantaloupe hybrid was grafted onto Lagenaria sicenaria and Cucurbita ficifolia. Non-grafted plants were used as control with both soilless culture systems. The results indicated that NFT as soilless culture system led to significant increase on plant growth characters i.e. plant height, leaves number/plant and stem thickness compared to traditional growing media. Grafting positively affected plant growth i.e. plant height, leaf number and stem thickness. Water consumption was affected also by grafting where the highest water consumption was recorded with cantaloupe plants grown in NFT system and grafted into Lagenaria sicenaria rootstock. Although growing media saved water use by plants from $85-87 \%$ in comparison with estimated water requirement calculated according pan evaporation method, the yield was low with using media cultivation system in comparison with yield of the plants grown in NFT system which saved only $39-41 \%$ of estimated water requirement increases in fruit yield and fruit size were recorded with grafted plants and this clear which may be due to utilization of the vigorous root system of the rootstocks. These grafted plants also shows increasing in minerals uptake when compared with nongrafted plants. In general, plants grown in NFT system produced fruits characterized with superior quality, high yield, rapid harvest, and high nutrient content.
\end{abstract}

Key words: cantaloupe, grafting, Nutrient film technique (NFT), Substrate culture, water consumption, Fruit yield.

\section{INTRODUCTION}

Grafting is currently practiced worldwide on many high-value cucurbitaceous and solanaceous crops such as watermelon [Citrullus lanatus], melon (Cucumis melo 
L.), cucumber (Cucumis sativus L.), tomato (Solanum lycopersicum L.), eggplant (S. melongena L.), and pepper (Capsicum. anuum L) for both open-field production and protected culture ( Lee and Oda, 2003; Davis et al., 2008 and Lee et al., 2010), it's given the physiological and phenotypic modifications causing by grafting with selected, vigorous rootstocks, it is likely that inhancing irrigation and fertilization management for maximizing crop yield may differ between grafted vs. and nongrafted vegetable production (Menda et al., 2006).

Grafted plants, which provide increased yield and, consequently, higher profit, can be become high value to farmers. Furthermore, in many of the most economically important vegetable crops, increases in fruit yield are a result of increased fruit size (Pogonyi et al., 2005). Owing to their utilization of the vigorous root system of the rootstocks, grafted plants usually show increasing uptake of water and minerals when compared with self-rooted plants (Lee and Oda 2003; Marios et al., 2017). Research has shown that possible mechanisms for increased yield are likely the result of increased water and nutrient uptake by vigorous rootstock genotypes. Uptake of macronutrients such as phosphorus and nitrogen was enhanced by grafting (Ruiz and Romero 1999, Leonardi, Giuffrida 2006, Menda et al., 2006, Schwarz et al., 2013 and Nawaz et al., (2016). Grafting muskmelon on inter-specific rootstocks has been reported to enhance photosynthesis and translocation of sugars in muskmelon leaves (Yi-Fei Liu, 2011).

Hydroponics is an eco-industrial technology for the production of commercial crops in nutrient rich solutions, instead of soil (Resh, 2012 and Jones Jr., 2016). Hydroponic crop production has significantly increased in recent years worldwide, as it allows a more efficient use of water and fertilizers, as well as a better control of climate and pest factors. Hydroponic production increases crop quality and productivity, which results in higher competitiveness and economic incomes (Savvas, et al., 2013, Singer et al., 2013 and Burrage 2014). Soilless culture enables growers to manage the supply of essential nutrients to crops more efficiently and accurately than traditional field systems (Jones, 1997; Resh, 2012). A soilless culture system is providing the plants with adequate concentrations of essential nutrients (Hochmuth and Hochmuth, 2001; Resh, 2012). Among soilless culture systems, NFT showed the best vegetative growth, yield and N, P and K of leaves contents (Singer et al.,2013)

In the conventional farming the loss of water from the vegetative surface through the combined processes of plant transpiration and soil evaporation is called Evapotranspiration (ET) and both environmental factors (solar radiation, temperature, vapor pressure deficit, wind and soil moisture) and biological factors including type of vegetation, foliage geometry and foliage density factors affect ET (Penman, 1948). 
Several methods have been developed to estimate crop ET. Most methods for that can by uses weather data to provide an estimate of reference (or potential) evapotranspiration (ETo), often convert the ETo to "actual" ET using a multiplicative factor known as a crop coefficient (Kc): ET = Kc $x$ ETo.

Hydroponic farming Evapotranspiration (ET) is the loss of water from a vegetative surface through the plant transpiration processes only and of course environmental and biological factors will affect ET, in this case the actual ET calculated as fellows: $\mathrm{ET}=\mathrm{Kc} \times \mathrm{x}$ transpiration.

In order to gain benefit from the soilless technology as well as grafting this experiment was designed to study the efficiency of water use by grafted cantaloupe grown under to soilless cultures system i.e. NFT and substrate culture mixture.

\section{MATERIALS AND METHODS}

The experiments were carried out in shaded greenhouse at the field experimental of Solar Energy Department in National Research Center, Egypt during summer of the two successive seasons of 2016 and 2017. The objectives of this investigation was to study the effect of grafted cantaloupe rootstocks and soilless culture systems on the water consumption and how can the hydroponic systems and grafting saving the irrigation water in compression with irrigation requirements of cantaloupe calculated based on pan evaporation method.

Thus, this study included the following two main topics:

A. Grafted rootstocks: Lagenaria sicenaria, Cucurbita ficifolia compared with nongrafted

B. Soilless culture system: Nutrient Film Technique (NFT) system and substrate culture (mixture of 1 peat, 1 vermiculite and1 perlite).

The split plot design with three replicates was used, where the culture systems was arranged in the main plots, and the rootstock treatments were assigned at in the sub plots. The cantaloupe plants (Cucumis melo L.) F1 hybrid Galia transplants were grafted onto two wild rootstocks under study, and non-grafted Galia hybrid transplants were used as check.

Accumulative irrigation requirement of cantaloupe plants according to pan evaporation method (Litter/plant) are shown as the following :

\begin{tabular}{|c|c|c|c|c|c|c|c|c|c|c|}
\hline Week & $1^{\text {st }}$ & $2^{\text {nd }}$ & $3^{\text {th }}$ & $4^{\text {th }}$ & $5^{\text {th }}$ & $6^{\text {th }}$ & $7^{\text {th }}$ & $8^{\text {th }}$ & $9^{\text {th }}$ & $10^{\text {th }}$ \\
\hline $\begin{array}{c}\text { WR } \\
\text { according } \\
\text { to pan } \\
\text { method }\end{array}$ & 5.41 & 10.83 & 16.24 & 21.66 & 52.93 & 84.21 & 115.49 & 146.77 & 178.18 & 209.59 \\
\hline
\end{tabular}

Seeds of rootstocks were sown in seedling trays (84 cells) on $10^{\text {th }}$ of March (4-5 days earlier than cantaloupe seeds of the scion).After germination and 
appearance of the first true leaf of rootstock, seedlings were planted in $10 \mathrm{~cm}$ diameter pots. Seedlings of rootstock were picked between the two cotyledons after removing the top of the seedling by razor blade, creating a V-shaped cut between the cotyledons. An inverse V-shape cut was made on the stem of the scion, $2 \mathrm{~cm}$ below the cotyledons, to fit the cut in the rootstock. Scion and rootstocks were held with a grafting clip. The seedlings were placed under plastic tunnel for optimum temperature and humidity. The compatibility was determined after 7 days (after grafting stage) in relatively high temperature $\left(25-30^{\circ} \mathrm{C}\right)$, watching the new growth on the scion. The plastic tunnel was gradually opened for adaptation and preparing the grafting seedlings for transplanting in the plastic house (Oda 1994). Transplants were set up, in first week of April in both growth seasons, in NFT gullies of $0.3 \mathrm{~m}$ wide, $5 \mathrm{~m}$ long and $6 \mathrm{~cm}$ height. Plants were placed in the center of the gullies at a distance of $0.5 \mathrm{~m}$ between plants. Nutrient solution analysis consist from $\mathrm{N}=60 \mathrm{ppm} ; \mathrm{P}=30 \mathrm{ppm} \mathrm{dm}-3$; $\mathrm{K}+=280 \mathrm{ppm} ; \mathrm{Ca}+2=26 \mathrm{ppm} ; \mathrm{Mg}+2=11 ; \mathrm{Fe}=6 \mathrm{ppm} ; \mathrm{Mo}=0.3 \mathrm{ppm} ; \mathrm{Cu}=0.5 \mathrm{ppm} ;$ $\mathrm{Zn}=2 \mathrm{ppm}$; was used. Electrical conductivity of the solution tank was adjusted 2-2.5 $\mathrm{dS} / \mathrm{m}(\mathrm{EC})$, and $\mathrm{PH}$ was kept at 6-6.5.

Plants were trained and pruned by removing the side shoots and flowers up to the $4^{\text {th }}$ internodes and then the side shoots were preserved, but they were pruned, leaving two internodes.

Data recorded:

1- Vegetative growth parameters, i.e., plant height, leaf number, stem thickness and fresh root weight were recorded.

2- Daily water consumption was measured to calculate the weekly accumulative water consumption per plant.

3- Fruit yield ( $\mathrm{Kg}$ per plant) and some fruit characters: Harvesting was started 75 days after transplanting and different fruit quality i.e. fruit diameter, length, flesh thickness, main weight and TSS were recorded.

4- Water use efficiency: It was calculated according to Begg and Turner (1976) equation as follows and expressed as water economy.

water economy $=\frac{\text { Fruit yield } / \text { plant }(\mathrm{kg})}{\text { Water consumption }(\mathrm{L} / \text { plant })}=\cdots \mathrm{kg} / \mathrm{L}$

\section{5-NPK contents}

Mature non-senescent leaf samples from $5^{\text {th }}$ node from apex were taken to determine NPK contents. Plant leaves samples were oven dried at $60^{\circ} \mathrm{C}$. After drying samples were ground using a pestle and mortar for determination of mineral 
composition. Ash of plant samples was digested using the $\mathrm{H}_{2} \mathrm{SO}_{4}$ and $\mathrm{H}_{2} \mathrm{O}_{2}$ as described by Cottenie (1980). The extracted samples were used to determine of NPK. Nitrogen concentration in leaves was determined using the modified micro-Kjeldahl method as described by Plummer (1971). phosphorus concentration in leaves was determined using calorimetrically according to Juckson 1958, and potassium concentration in leaves was measured by flame photometrically as described by Piper (1950).

\section{Statistical analysis:}

All obtained data was subjected to the statistical analysis of variance (ANOVA) according to Gomez and Gomez (1984) and L.S.D. were determined at the level $\mathrm{P} \geq 0.05$

\section{RESULTS AND DISCUSSION}

\section{1- Vegetative Growth}

The tabulated mean values of the vegetative growth of cantaloupe plants are shown in table (1a). Growth characters under this study i.e., plant height, leaf number, and stem thickness revealed that, the highest vegetative growth values i.e., plant height, leaf number, and stem thickness were obtained by plants grown in NFT culture system. These results are due to the higher rate of roots absorption for the nutrient solution in Nutrient Film Technique (NFT) soilless culture system. These results are in agreement with Economakis \& Krulj, 2001 and Singer et al., 2013. This could be due to that immersing cantaloupe roots in the nutrient solution all the time makes buffer for the temperature. Data also (table $1 \mathrm{~b}$ ) showed slightly significant differences between plants grafted into Lagenaria sicenaria or Cucurbita ficifolia rootstocks on the value of vegetative growth and both of them were recorded significant increases in vegetative growth in comparison with non-grafted plants. The interpretation of these results may be due to the increases in roots weight of the grafted plants (Schwarz et al., 2013).

Concerning effect of the interaction between cultivation system and grafting, data in Table (2), showed that plants grown in NFT system and grafted into Lagenaria sicenaria had the highest vegetative growth followed by plants grafted into Cucurbita ficifolia rootstocks and grown in the same soilless culture system. While the lowest values were obtained from non-grafted plants and cultivated under conditions of substrate culture (mixture of 1 peat, 1 vermiculite and 1 perlite). This shows the relationship between the grafting, soilless culture system and the efficiency of the roots in the absorption of the nutrient solution and the effect of all this on plant growth. Fresh root weight was highly affected with soilless system cultivation where highest value of root weight are recorded with NFT system (table 1a). The effect of 
rootstocks on fresh root weight was shown in table 1b. The highest fresh root weight was recorded with cantaloupe grafted into Lagenaria sicenaria rootstock followed by plants grafted into Cucurbita ficifolia rootstock and the lowest value of fresh root weight was recorded with non-grafted plants. Concerning the interaction between cultivation system and rootstocks, recorded data in (table 2) showed that the highest value of fresh root weight was recorded with plants grafted into Lagenaria sicenaria rootstock and the lowest fresh root weight was recorded with non-grafted plants grown in substrate media.

\section{2- Water consumption}

Data in table $3 a$ and fig 1 show the effect of growing media (substrate culture and NFT) on water consumption of cantaloupe plants. Substrate culture system recorded the lowest water consumption in comparison with NFT system and both of them recorded the lower water consumption in comparison with estimated water requiems according to Pan Evaporation method. These results agree with Singer et al., 2013 .

Concerning the effect of grafting on the water consumption of cantaloupe plants, data in Fig (3b and fig.2) show that, all type of grafted plants increased water consumption use in comparison with non-grafted and this increase was significant. While, all grafted plants into both Lagenaria sicenaria or Cucurbita ficifolia and nongrafted plant recoded significant decreases in water consumption in comparison with estimated water requirement according to Pan Evaporation method. Some researchers have shown that possible mechanisms for increased yield are likely the result of increased water and nutrient uptake by vigorous rootstock genotypes (Ruiz\&Romero 1999, Lee \& Oda 2003, and Leonardi, Giuffrida 2006).

As for the interaction effect between soilless culture systems and grafting, data in table 4 and fig. 3 showed that the highest value of water consumption was recorded with plants grafted into both Lagenaria sicenaria or Cucurbita ficifolia rootstocks and grown in NFT cultivation system while, the lowest value of water consumption was recorded with non-grafted plants grown in substrate media. 


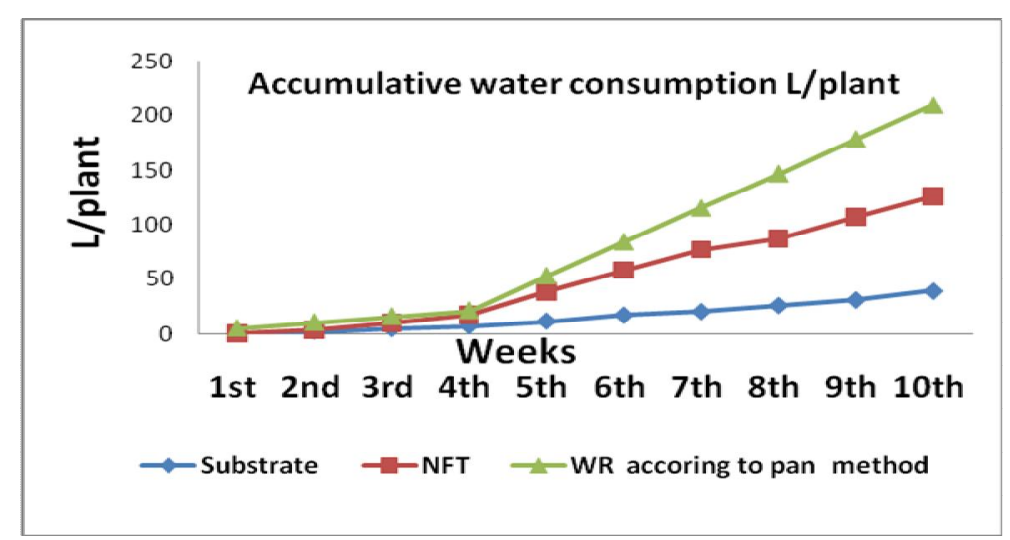

Fig. 1. Effect of growing substrate on water consumption of cantaloupe plants

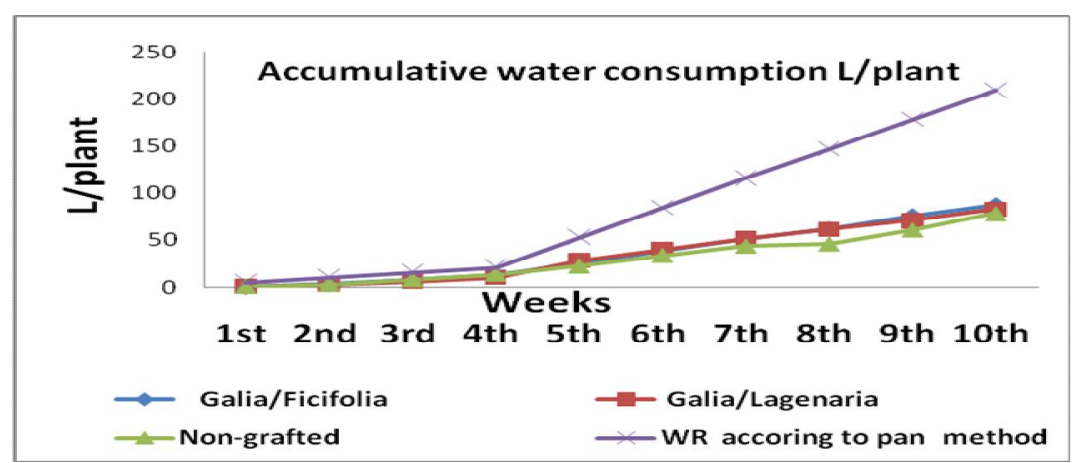

Fig. 2. Effect of rootstocks on water consumption of cantaloupe plants

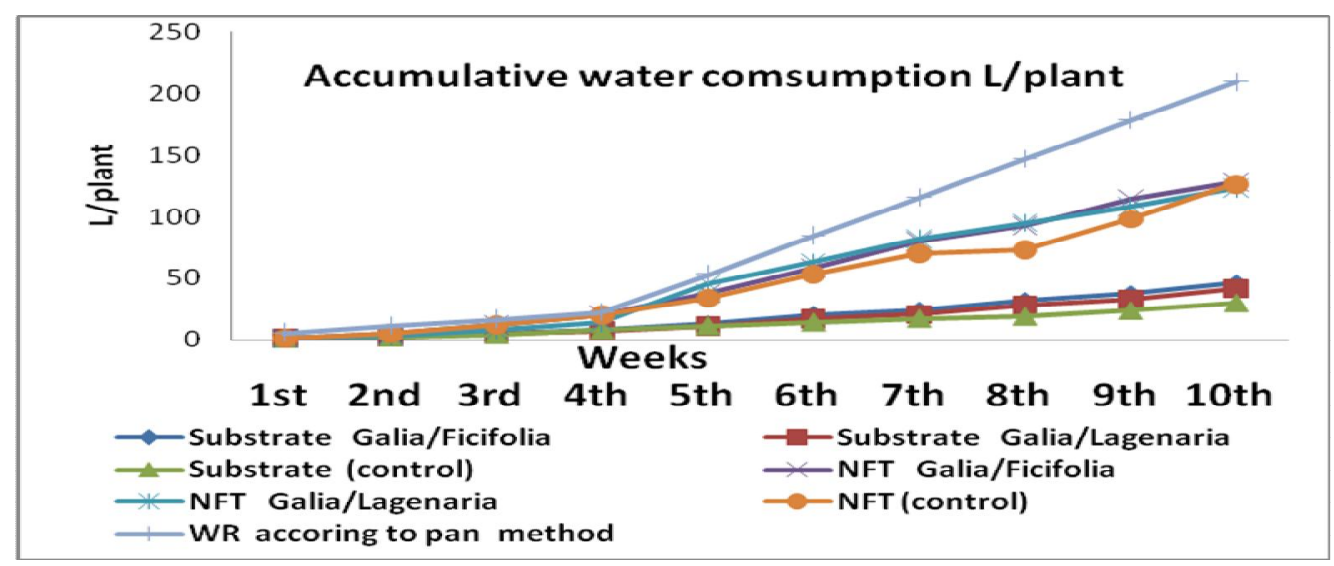

Fig. 3. The interaction effect between rootstocks and growing substrate on water consumption of cantaloupe plants

\section{3- Water use efficiency (WUE)}

Data in fig. 4 showed that substrate culture recorded highest water use efficiency (WUE) in comparison with NFT system. These results may due to the increasing of root growth and weight of plants grown in NFT gullies which led to an increasing transpiration rate of plant leaves results to more increase in water consumption. These results are similar with the results reported by Singer et al., 2013. 
Concerning the effect of grafting (fig.5) results showed that, both type of grafted plants decreased water use efficiency in comparison of non-grafted.

The interaction effect between soilless culture system and grafting (fig.6), showed that the highest value of water use efficiency was recorded with non-grafted plants grown in substrate media while, plants grafted into both Lagenaria sicenaria or Cucurbita ficifolia rootstock and grown in NFT cultivation system had the lowest value of water use efficiency. The lowest water use efficiency was recorded with nongrafted plants grown in NFT system.

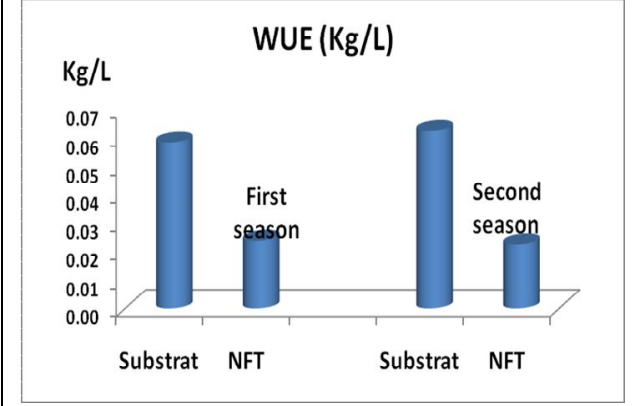

Fig. 4. Effect of growing substrate on water use efficiency of cantaloupe plants WUE $=$ water use efficiency

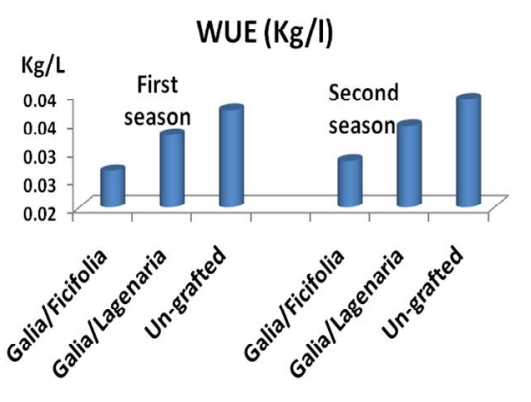

Fig. 5. Effect of rootstocks on water use efficiency of cantaloupe plants WUE $=$ water use efficiency

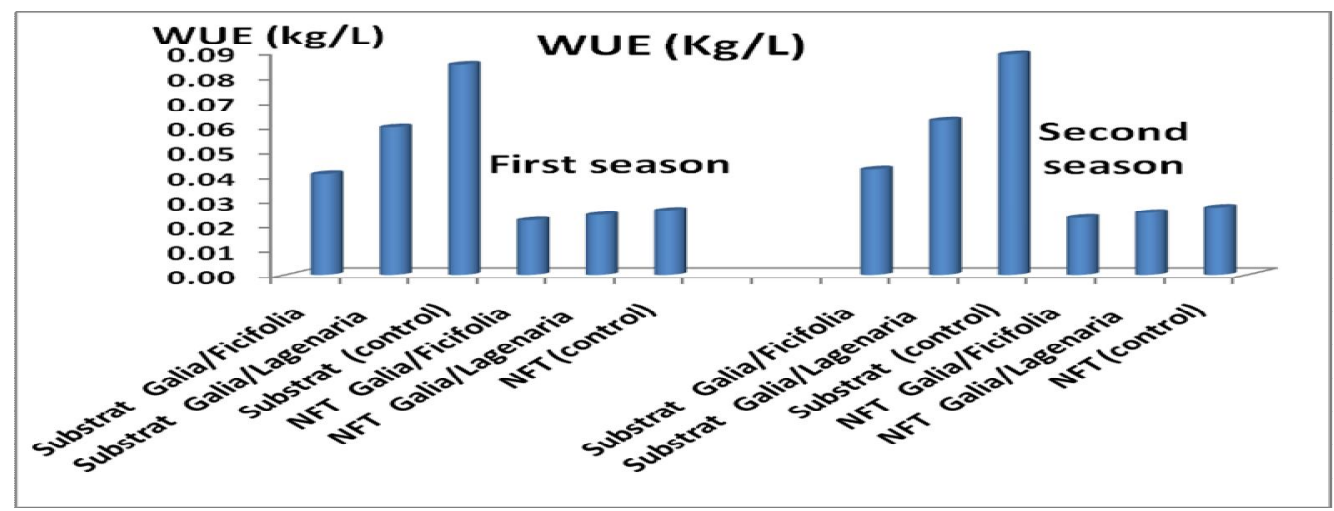

Fig. 6. Effect of the interaction between rootstocks and growing substrate on water use efficiency $(\mathrm{Kg} / \mathrm{L})$.

\section{4- $\quad$ Fruit yield and fruit characteristics:}

The effect of culture system and grafting on fruit yield and some fruit characters are shown in Tables ( $5 a \& b$ ). It is obvious that, the plants grown in NFT system recorded the highest fruit yield per plant by about $30 \%$ in comparison with media cultivation (Table 5a). These results agree with Singer et al., 2013. Data in table (5b) also showed that grafting Galia cantaloupe either into Lagenaria sicenaria 
or Cucurbita ficifolia rootstock increased total yield per plants comparing to nongrafted plant (16 and $20 \%$ respectively). These increases reported also by Ruiz $\&$ Romero 1999, and Lee \& Oda 2003 and Pogonyi et al., 2005.Concerning the effect of interaction (table 6), data showed that the yield of cantaloupe plants grafted into Lagenaria sicenaria and grown in NFT system produced the highest total yield and the lowest total yield was occurred by non-grafted plants grown in media system. The percentage of increases was 32, 36, 57 and $74 \%$ for plants grown in media system and grafted into Cucurbita ficifolia, plants grown in media system and grafted into Lagenaria sicenaria, plants grown in NFT system and grafted into Cucurbita ficifolia, plants grown in NFT system and grafted into Lagenaria sicenaria respectively in compassion with non-grafted plants grown in media system.

Fruit characteristics i.e. average of fruit weight, number, length, diameter, flesh thickness and number of fruits per plant is shown in tables 5and 6. Data showed that the highest fruit weight was obtained by NFT system and the lowest fruit weight was recorded when using substrate cultivation system. Plants grown in NFT system gave higher fruit weight compared with those grown media system. The other fruit characteristics showed the same trained. It was notable from obtained data that fruit number per plant was significantly decreased with media system which can clarify the reason of significant increases in the yield from plants grown in NFT system in comparison with the yield of plants grown in media system. The enhancing and increasing in fruit characteristics with NFT system may be due to the availability of nutrition ions around the plants throughout the 24 hours of continuously closing system of nutrient solutions within the system.

The effect of grafting on fruit characteristics (table $5 b$ ) presented in the same table showed that, The plants grafted into both Lagenaria sicenaria or Cucurbita ficifolia rootstocks have the highest fruit weight and fruit quality i.e. fruit length, diameter, flesh thickness, TSS and fruit number in comparison with non-grafted plants. These enhancing may be due to enhances photosynthesis and translocation of sugars in muskmelon leaves as reported by Yi-Fei Liu, 2011 and may also due to their utilization of the vigorous root system of the rootstocks, grafted plants usually show increased uptake of water and minerals when compared with self-rooted plants (Lee and Oda 2003).

The interaction between cultivation system and grafting (table 6) showed that Galia cantaloupe plants grafted into Lagenaria sicenaria and grown in NFT system has the highest average of fruit weight, number, length, diameter, flesh thickness and number of fruits per plant. 


\section{5- Leaf mineral content}

Data in Table 7a show the effect of growing media (substrate culture and NFT) on nitrogen, phosphorus and potassium contents (\%) in shoot of cantaloupe plants. Substrate culture system recorded significant decries in the value of $\mathrm{N}$ and $\mathrm{P}$ in comparison with NFT systems, while there were no significant differences between them in $\mathrm{K}$ content.

Concerning the effect of grafting on the mineral content of cantaloupe plants, data in Table 7b showed that, all grafted plants significantly increased NPK content in compassion of non-grafted. The highest NPK content was recorded with plants grafted into both Lagenaria sicenaria and the lowest NPK content was recorded with nongrafted plants. the positive effect of grafting on mineral uptake by plants have reported by many authors, Ruiz\&Romero 1999, Lee and Oda 2003 and Leonardi, Giuffrida 2006 Yi-Fei Liu, 2011.

As for the interaction effect between soilless culture systems and grafting (Table 8 ), the highest value of nitrogen content was recorded with plants grafted into Cucurbita ficifolia grown in substrate system while, the lowest value of water consumption use was recorded with plants non-grafted plant grown in substrate media. Non-grafted plant grown in substrate media recorded the lowest value of phosphorus in comparison with the rest of treatment and the differences between other treatments were very narrow and neglectable. Results also showed that all cantaloupe plants grown in NFT and grafted into system Lagenaria sicenaria or Cucurbita ficifolia slightly increased, potassium content in comparison with all plants grown in substrate media either grafted or non-grafted.

\section{CONCLUSION}

Under the condition of the experiment we can gain the benefit of hydroponic crop production systems which applied in recent years worldwide (as it allows a more efficient use of water and fertilizers, as well as it is consider a better control for climate and pest factors) and also the benefit of grafting which is also practiced worldwide now (for vigorous growth and better use of water and nutrient) to increases crop production, quality and productivity. Also, NFT system prove to be more suitable for higher production and best use of mineral although media system proven to be more effective in water use efficiency under experimental condition. Further work needs to be done on the wide range of rootstock under different climate condition in Egypt to find out the best one should be used for best productivity and quality. 
竎

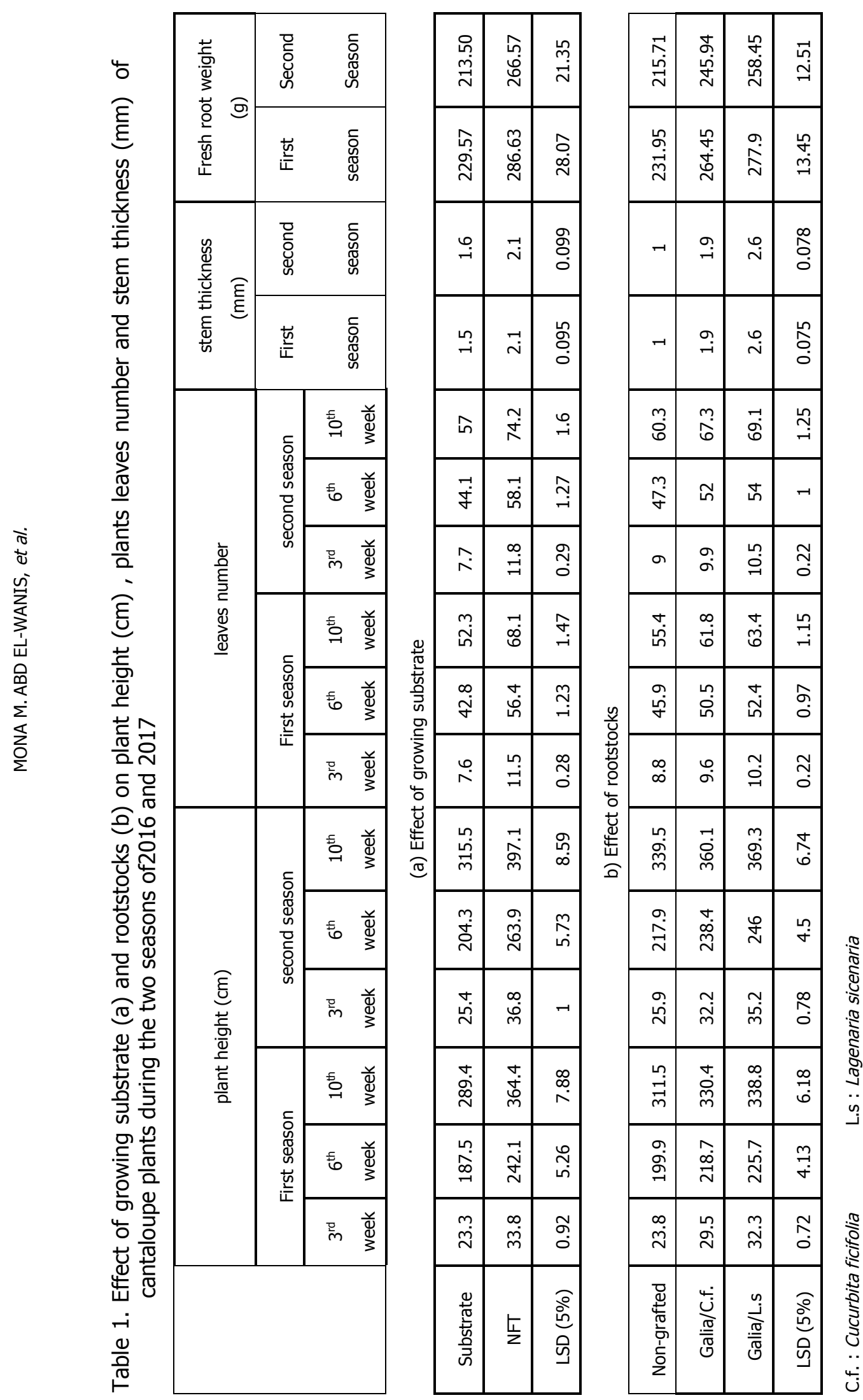




\begin{tabular}{|c|c|c|c|c|c|c|c|c|c|c|}
\hline \multirow{9}{*}{ 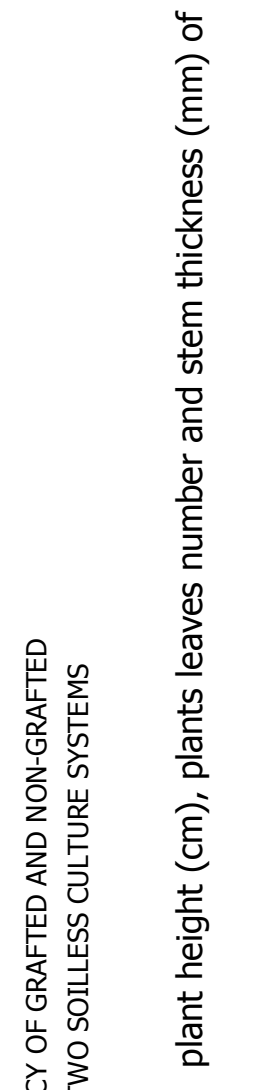 } & \multirow{2}{*}{ 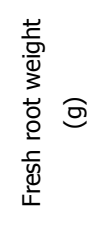 } & $\begin{array}{l}\bar{g} \\
\overline{\bar{g}} \\
\bar{\varpi}\end{array}$ & 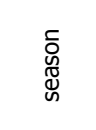 & 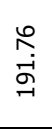 & \begin{tabular}{l}
\multirow{J}{0}{} \\
$\infty$ \\
$\stackrel{D}{N}$
\end{tabular} & $\begin{array}{l}\infty \\
\dot{0} \\
\text { iे }\end{array}$ & $\begin{array}{l}\stackrel{\circ}{\circ} \\
\stackrel{\sim}{\sim}\end{array}$ & $\underset{\sim}{\stackrel{N}{N}}$ & $\begin{array}{l}\vec{\infty} \\
\stackrel{\infty}{\infty} \\
\stackrel{\infty}{\infty}\end{array}$ & 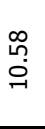 \\
\hline & & 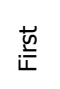 & 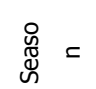 & 棺 & 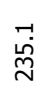 & 苟 & 今. & 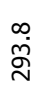 & $\stackrel{\dot{0}}{o}$ & 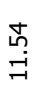 \\
\hline & \multirow{2}{*}{ 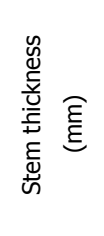 } & 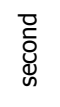 & 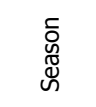 & $\stackrel{\infty}{0}$ & $\stackrel{6}{-}$ & $\stackrel{\sim}{\sim}$ & $ت$ & $\tilde{N}$ & $m$ & $\stackrel{m}{\stackrel{7}{0}}$ \\
\hline & & 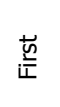 & 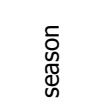 & $\stackrel{\infty}{0}$ & $\underset{-}{\circ}$ & $\stackrel{\sim}{N}$ & 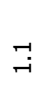 & $\stackrel{\sim}{N}$ & $\stackrel{9}{\mathrm{~N}}$ & $\stackrel{m}{0}$ \\
\hline & \multirow[b]{6}{*}{. } & \multirow{3}{*}{ 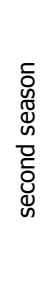 } & 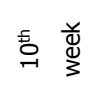 & $\begin{array}{l}\text { 字 } \\
\text { ஸे }\end{array}$ & $\stackrel{2}{i}$ & 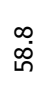 & 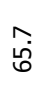 & $\stackrel{\llcorner}{\stackrel{1}{\curvearrowright}}$ & ֻू & $\stackrel{\vec{i}}{\vec{i}}$ \\
\hline & & & E & $\stackrel{\mathscr{q}}{\mathscr{\gamma}}$ & 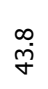 & 字 & iี & $\stackrel{m}{0}$ & 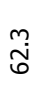 & $\underset{\text { N }}{\mathrm{i}}$ \\
\hline & & & 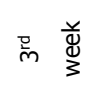 & $\stackrel{\leftrightarrow}{r}$ & $\stackrel{\bullet}{\wedge}$ & $\underset{\infty}{m}$ & 迥 & $\underset{\sim}{\stackrel{N}{\sim}}$ & 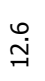 & लि \\
\hline & & \multirow{3}{*}{ 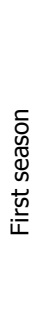 } & 总 & ڤั. & 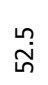 & ભి & $\stackrel{m}{0}$ & $\vec{i}$ & 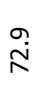 & ه্ \\
\hline & & & 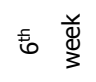 & $\hat{\vec{q}}$ & $\stackrel{\stackrel{n}{\sim}}{\stackrel{q}{r}}$ & $\underset{\dot{J}}{\dot{f}}$ & กั & $\stackrel{\substack{n \\
\infty}}{h}$ & : & \\
\hline \multirow{9}{*}{ 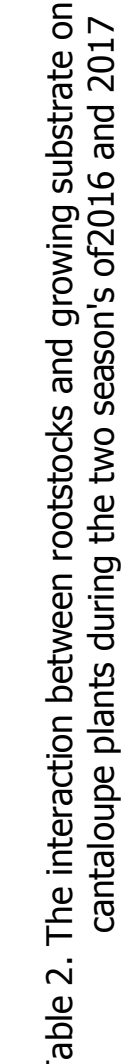 } & & & 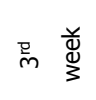 & $\stackrel{n}{n}$ & $\stackrel{+}{\sim}$ & $\vec{\infty}$ & on & $\stackrel{9}{\vec{j}}$ & $\stackrel{m}{\underset{N}{N}}$ & 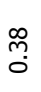 \\
\hline & \multirow{6}{*}{ 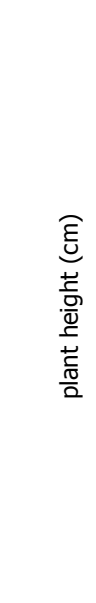 } & \multirow{3}{*}{ 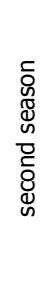 } & 总 & $\underset{\dot{m}}{\dot{i}}$ & 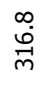 & $\underset{\substack{\infty \\
m}}{\infty}$ & 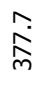 & $\begin{array}{l}\stackrel{n}{\infty} \\
\stackrel{\rho}{q}\end{array}$ & ma & تِ \\
\hline & & & E & 焉 & 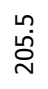 & $\overrightarrow{\vec{m}}$ & $\underset{\stackrel{d}{\vec{d}}}{\vec{d}}$ & 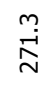 & $\stackrel{\infty}{\infty}$ & $\stackrel{\infty}{\sim}$ \\
\hline & & & 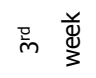 & $\stackrel{\circ}{i}$ & o̊ & $\stackrel{\infty}{\stackrel{\infty}{\sim}}$ & ָ̊ & $\stackrel{\stackrel{n}{P}}{\stackrel{m}{m}}$ & 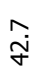 & $\stackrel{\leftrightarrow}{\stackrel{m}{r}}$ \\
\hline & & \multirow{3}{*}{ 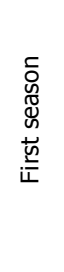 } & 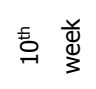 & 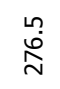 & 㝘 & $\vec{j}$ & $\begin{array}{l}\text { n } \\
\text { o } \\
\text { m }\end{array}$ & ֻ̃ & $\begin{array}{l}\dot{0} \\
\stackrel{0}{0} \\
\text { m }\end{array}$ & 审 \\
\hline & & & 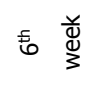 & $\stackrel{+}{\infty}$ & 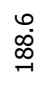 & 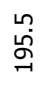 & ثं & $\begin{array}{l}\stackrel{\sigma}{ } \\
\stackrel{\infty}{\sim}\end{array}$ & 芩 & $\stackrel{n}{\rightarrow}$ \\
\hline & & & 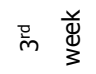 & $\begin{array}{l}\infty \\
\stackrel{\sim}{q}\end{array}$ & $\stackrel{\overbrace{}}{\sim}$ & 号 & $\stackrel{\AA}{i}$ & $\stackrel{+}{\stackrel{j}{\dot{m}}}$ & ָั & 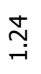 \\
\hline & & & & 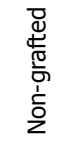 & 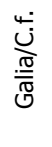 & 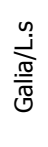 & $\begin{array}{l}\underline{g} \\
\frac{d}{0} \\
\frac{0}{5} \\
\frac{5}{2} \\
\frac{2}{2}\end{array}$ & 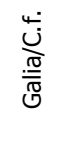 & 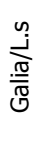 & \\
\hline & & & & 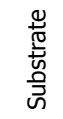 & & & $\frac{5}{2}$ & & & \\
\hline
\end{tabular}




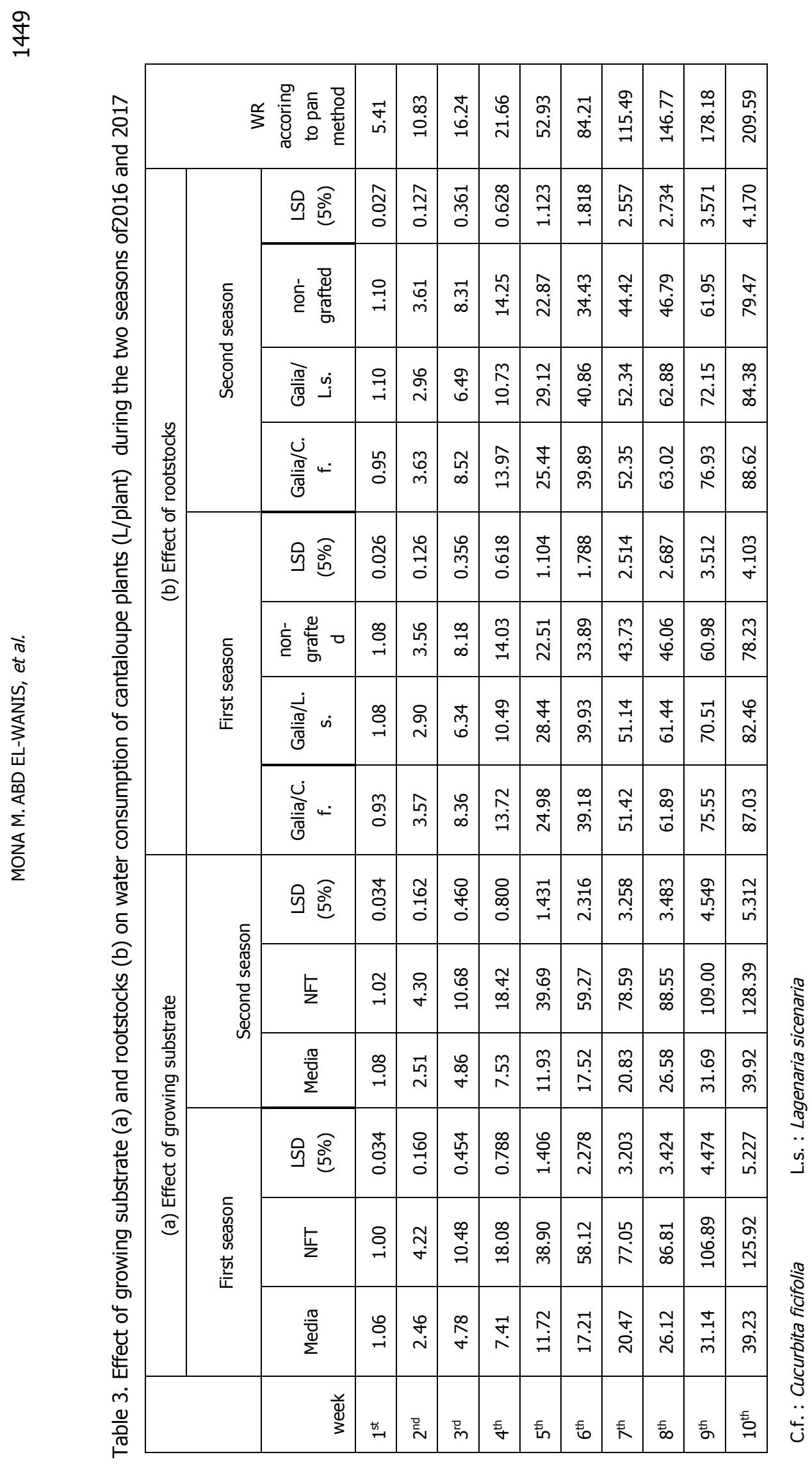




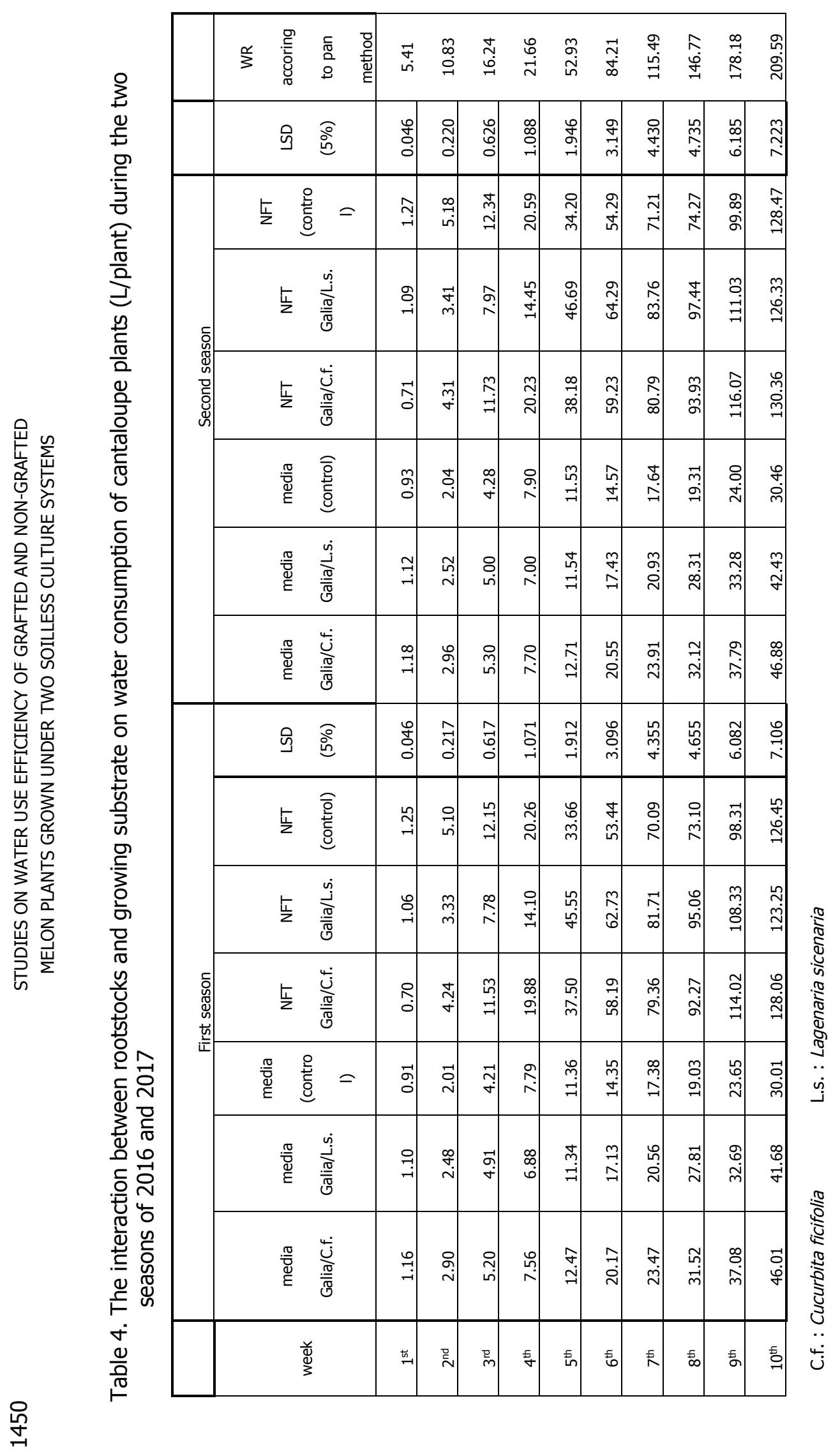


㔛

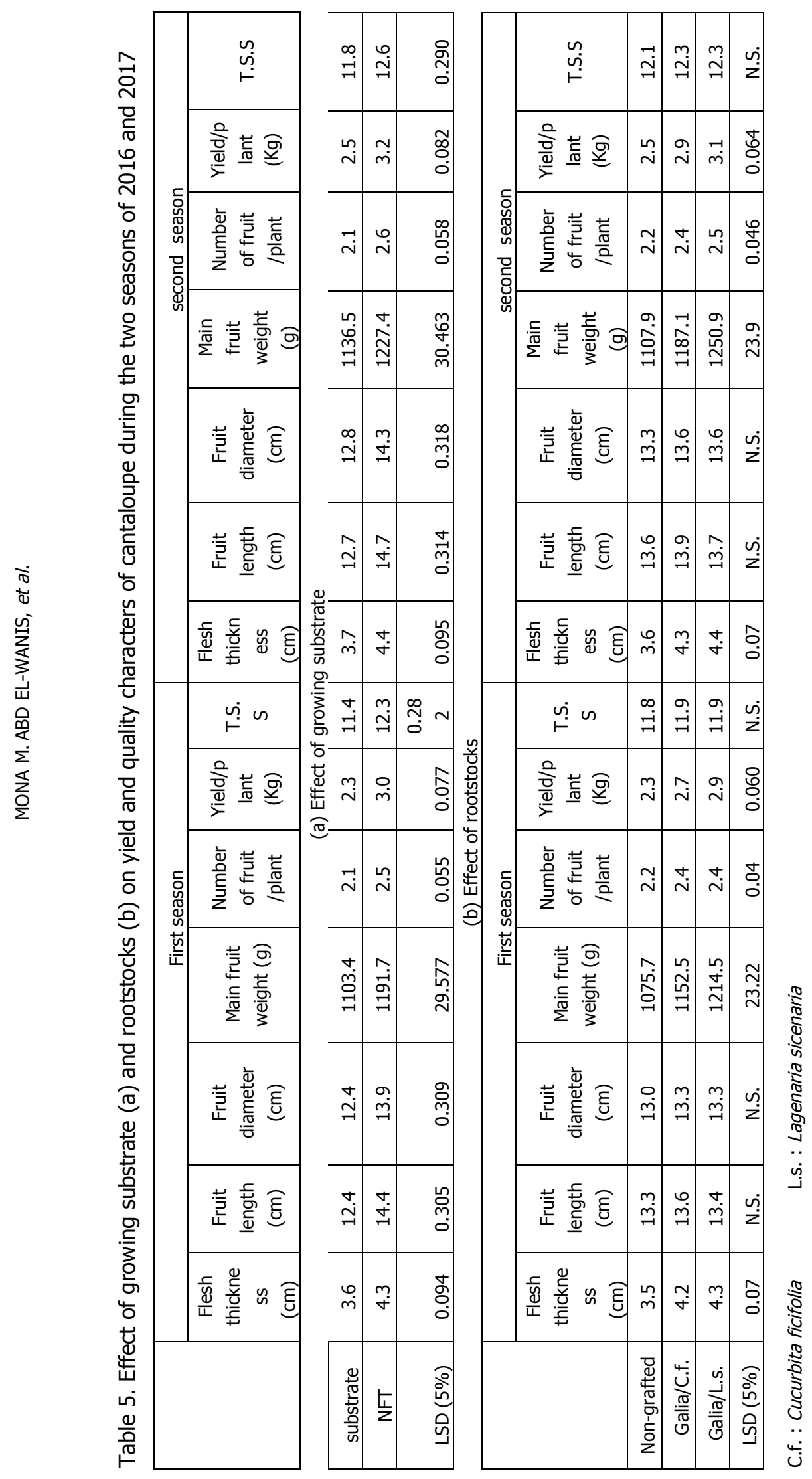




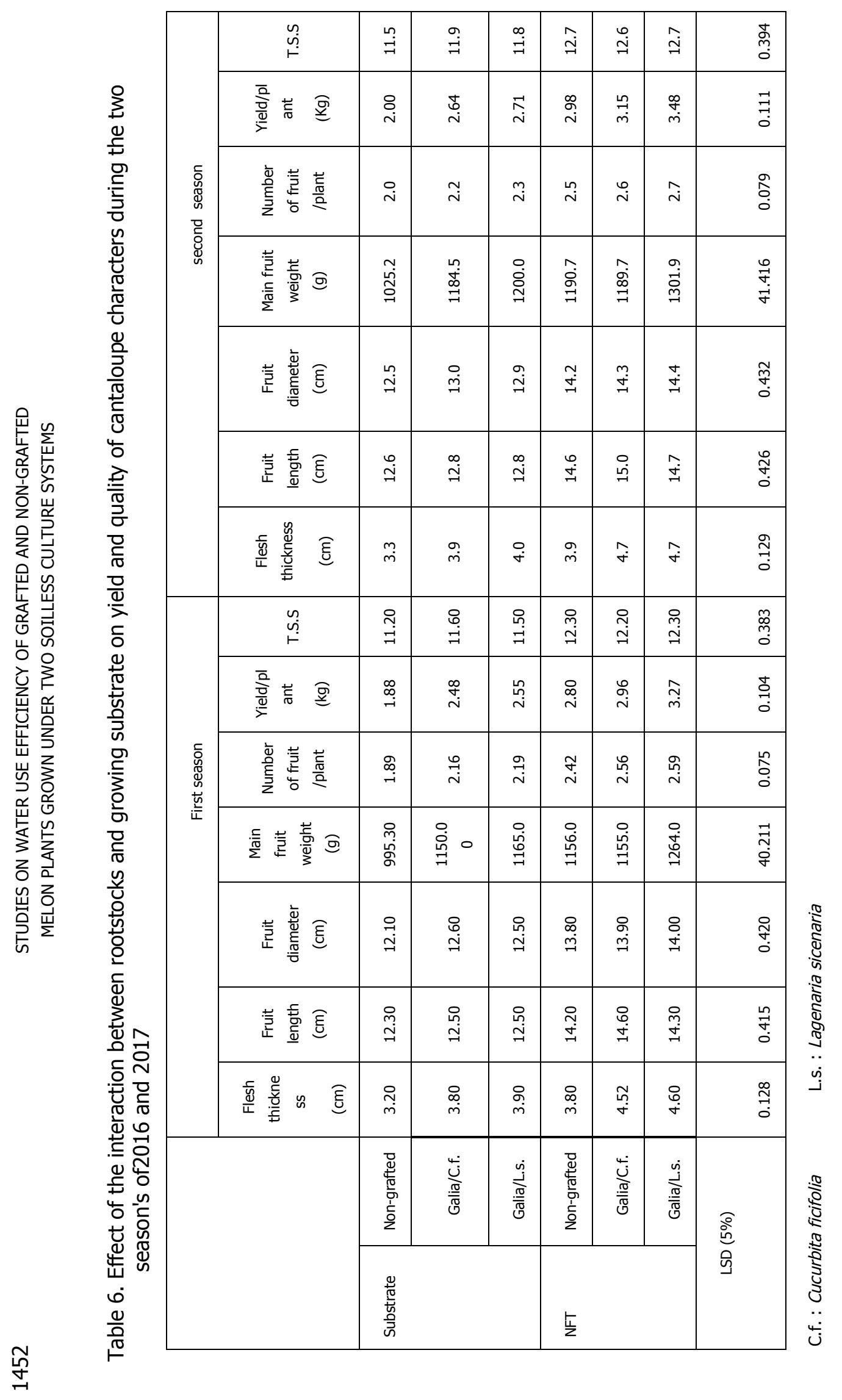


Table 7. Effect of growing substrate (a) and grafting (b) on N, P, and $K$ contents of cantaloupe leaves (\%) during the two seasons of 2016 and 2017.

\begin{tabular}{|c|c|c|c|c|c|c|}
\hline \multirow{2}{*}{} & \multicolumn{3}{|c|}{ First season } & \multicolumn{3}{c|}{ second season } \\
\cline { 2 - 7 } & $\mathrm{N} \%$ & $\mathrm{P} \%$ & $\mathrm{~K} \%$ & $\mathrm{~N} \%$ & $\mathrm{P} \%$ & $\mathrm{~K} \%$ \\
\hline
\end{tabular}

(a) Effect of growing substrate

\begin{tabular}{|c|c|c|c|c|c|c|}
\cline { 2 - 7 } Substrate & 4.23 & 0.48 & 3.57 & 4.38 & 0.50 & 3.69 \\
\hline NFT & 4.33 & 0.52 & 3.60 & 4.49 & 0.54 & 3.73 \\
\hline LSD (5\%) & 0.108 & 0.013 & N.S. & 0.111 & 0.013 & N.S. \\
\hline \multicolumn{7}{|c|}{ (b) Effect of grafting } \\
\hline \multicolumn{7}{|c|}{ Non-grafted } \\
\hline Galia/C.f. & 4.05 & 0.45 & 3.30 & 4.19 & 0.47 & 3.42 \\
\hline Galia/L.s. & 4.55 & 0.54 & 3.75 & 4.71 & 0.55 & 3.83 \\
\hline LSD (5\%) & 0.085 & 0.010 & 0.072 & 0.087 & 0.010 & 0.075 \\
\hline
\end{tabular}

C.f. : Cucurbita ficifolia

L.s. : Lagenaria sicenaria

Table 8. The interaction between grafting and growing substrate on $\mathrm{N}, \mathrm{P}$ and $\mathrm{K}$ content of cantaloupe leaves (\%)during the two seasons of 2016 and 2017.

\begin{tabular}{|c|c|c|c|c|c|c|c|}
\hline \multirow{2}{*}{} & \multicolumn{3}{|c|}{} & \multicolumn{3}{c|}{ First season } & \multicolumn{2}{c|}{ second season } \\
\cline { 3 - 8 } & $\mathrm{N} \%$ & $\mathrm{P} \%$ & $\mathrm{~K} \%$ & $\mathrm{~N} \%$ & $\mathrm{P} \%$ & $\mathrm{~K} \%$ \\
\hline \multirow{3}{*}{ Substrate } & Non-grafted & 3.90 & 0.39 & 3.10 & 4.02 & 0.40 & 3.19 \\
\cline { 2 - 8 } & Galia/C.f. & 4.20 & 0.52 & 3.80 & 4.33 & 0.53 & 3.91 \\
\cline { 2 - 8 } & Galia/L.s. & 4.60 & 0.54 & 3.80 & 4.74 & 0.55 & 3.91 \\
\hline \multirow{3}{*}{ NFT } & Non-grafted & 4.20 & 0.51 & 3.50 & 4.33 & 0.52 & 3.61 \\
\cline { 2 - 8 } & Galia/C.f.. & 4.30 & 0.53 & 3.60 & 4.43 & 0.54 & 3.71 \\
\cline { 2 - 8 } & Galia/L.s. & 4.50 & 0.53 & 3.70 & 4.64 & 0.54 & 3.81 \\
\hline \multirow{2}{*}{ LSD (5\%) } & & 0.147 & 0.018 & 0.126 & 0.151 & 0.018 & 0.129 \\
\hline
\end{tabular}

C.f. : Cucurbita ficifolia

L.s. : Lagenaria sicenaria 


\section{ACKNOWLEDGMENT}

The authors Acknowledge In-house projects office of National Research Center, Cairo, Egypt for providing research funding to conduct this study.

\section{REFERENCES}

1. Begg,J.E.and N.C.Turner 1976. Crop water deficits. Advances in Agron.,28,pp.189

2. Burrage, S.W., 2014. Soilless Culture and Water Use Efficiency for Greenhouses in Arid, Hot climates.

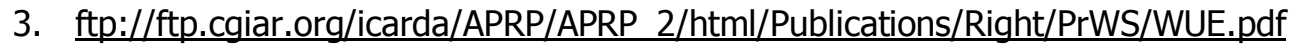
Cottenie, A. 1980. Soil and plant testing as a basis of fertilizer recommendation. FAO Soil Bull.., 3812.

4. Davis, A.R., P. Perkins-Veazie, Y. Sakata, S. Lo'pez-Galarza, J.V. Maroto, S.G. Lee, Y.C. Huh, Z. Sun, A. Miguel, S.R. King, R. Cohen, and J.M. Lee. 2008. Cucurbit grafting. Crit. Rev. Plant Sci. 27:50-74.

5. Economakis, C.D. and L. Krulj, 2001. Effect of root - zone warming on strawberry plants grown with Nutrient Film Technique (NFT). Acta Hort., 548: 189-196.

6. Gomez, K.A. and A.A. Gomez, 1984. Statistical procedures for Agriculture Research. International Rice Research, institute, $2^{\text {nd }}$ Ed. John Wiley and sons. Inc. New-York, 680p

7. Hochmuth, G. J., E. Hanlon, and R. Hochmuth. 2001. Nitrogen crop nutrient requirements for muskmelons grown in various polyethylene mulch systems. Florida Agriculture Experiment Station Research Report, Suwannee Valley AREC 91-5.

8. Jackson, N.L. 1958. Soil chemical Analysis constable. LTD.Co., London, 498 pp.

9. Jones Jr., J.B., 2016. Hydroponics: a Practical Guide for the Soilless Grower. CRC Press, Library of Congress, the United States of America.

10. Jones, J. B. 1997. The essential elements, pp. 23-49.

11. Lee, J.M. and M. Oda. 2003. Grafting of herbaceous vegetable and of ornamental crops. Hort. Rev. 28:61-124.

12. Lee, J.M., C. Kubota, S.J. Tsao, Z. Bie, P.H. Echevarria, L. Morra, and M. Oda. 2010. Current status of vegetable grafting: Diffusion, grafting techniques, automation. Sci. Hort. 127: 93-105

13. Leonardi C., Giuffrida F., 2006. Variation of plant growth and macronutrient uptake in grafted tomatoes and eggplants on three different rootstocks. European Journal of Horticultural Science, 71: 97-101.

14. Marios C. Kyriacou, Youssef Rouphael, Giuseppe Colla, Rita Zrenner and Dietmar Schwarz 2017. Vegetable Grafting: The Implications of a Growing Agronomic 
Imperative for Vegetable Fruit Quality and Nutritive Value. Front Plant Sci. 2017; 8: 741.

15. Menda N., Eshed Y. and Zamir D. 2006. Reciprocal grafting of 61 randomly selected morphological tomato mutants reveal no evidence for systematically transmitted phenotypic alterations. Tomato Genet. Coop. 56 29-32.

16. Nawaz, M.A., Imtiaz, M., Kong, Q., Fei, C., Ahmed, W., Huang, Y. and Bie, Z. 2016. Grafting: a technique to modify ion accumulation in horticultural crops. Frontiers in Plant Science 7, 1457

17. Oda, M. 1994. New grafting methods for fruit bearing vegetables in Japan. Japan Agric. Res. Quart., 29:187-194.

18. Penman, H.L. 1948. Natural evaporation from open water, bare soil and grass. Proc. Roy. Soc. London, A193:120-146.

19. Piper, C.S. 1950. Sol and Plant Analysis. Inter. Sci., New York, 368pp.

20. Plummer, D.T. 1971. An Introduction to practical Biochem., Mc Graw Hill Book Company (UK) Limited, 124pp.

21. Pogonyi A., Pek Z., Helyes L. and Lugasi A., 2005. Effect of grafting on the tomato' $s$ yield, quality and main fruit components in spring forcing. Acta Elimentaria, 34: 453-462.

22. Resh, H.M., 2012. Hydroponic Food Production: a Definitive Guidebook for the Advanced Home Gardener and the Commercial Hydroponic Grower. CRC Press, Taylor \& Francis Group, Boca Raton.

23. Ruiz J.M. and Romero L., 1999. Nitrogen efficiency and metabolism in grafted melon plants. Scientia Horticulturae, 81: 113-123.

24. Savvas, D., Gianquinto, G., Tuzel, Y. and Gruda, N. 2013. Soilless Culture. FAO Plant Production and Protection Paper No. 217: Good Agricultural Practices for Greenhouse Vegetable Crops.

25. Schwarz, D., Öztekin, G.B., Tüzel, Y., Brückner, B. and Krumbein, A. 2013. Rootstocks can enhance tomato growth and quality characteristics at low potassium supply. Scientia Horticulturae 149, 70-79.

26. Singer, S.M., A.M.M. El-Tanahy, U.A. El-Behairy and E.H. Abd El-Samad 2013. Growth and Productivity of Cantaloupe Plants Grown under Different Soilless Culture Systems. Journal of Applied Sciences Research, 9(8): 5294-5302, 2013

27. Yi-Fei Liu, Hong-Yan Qi, Chun-Ming Bai, Ming-Fang Qi, Chuan-Qiang Xu, JingHong Hao, Yan Li1 and Tian-Lai Li 2011. Grafting Helps Improve Photosynthesis and Carbohydrate Metabolism in Leaves of Muskmelon. International Journal of Biological Sciences 7(8):1161-1170. 


\title{
دراسات على كفاءة الاستهلاك المائى لنباتات الكنتالوب المطعومة و النامية تحت نظامين

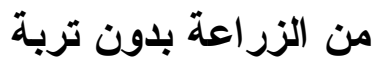

\author{
منى عبد الونيس محمد1 - محمود محمد حامد عبد الباقى2 - سمير رجب أحمد2 \\ 1. قسم الزراعات المحمية - معهُ بحوث البساتين - مركز البحوث الزراعية

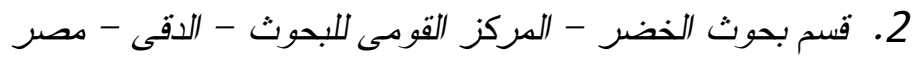

تهدف هذه الدراسة إلى معرفة نأثير تطعيم نباتات الكانتالوب هجين جاليا على بعض الاصول

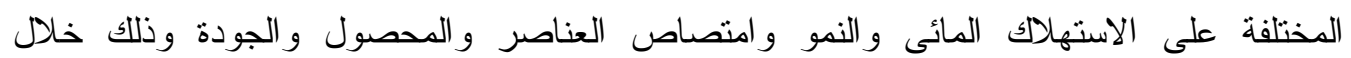
موسمين للزر اعة 2016 و 2017 حيث تم مقارنة النباتات المطعومة بغير المطعومة تحت نظامين

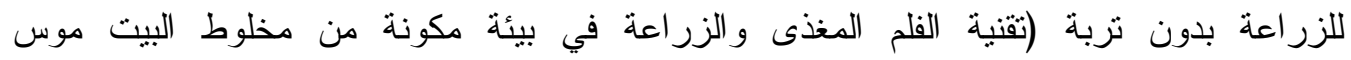

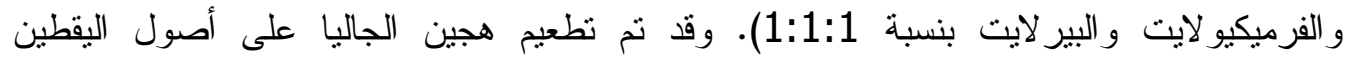
Cucurbita ficifolialagenaria sicenaria

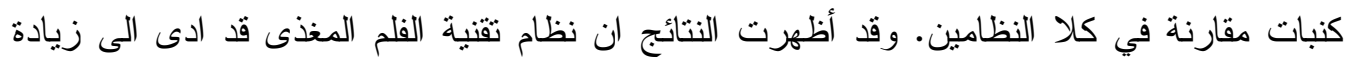
معنوية فى صفات النمو مثل ارتفاع النبات و عدد الاوراق بالنبات الواحد وسمك الساق مقارنة

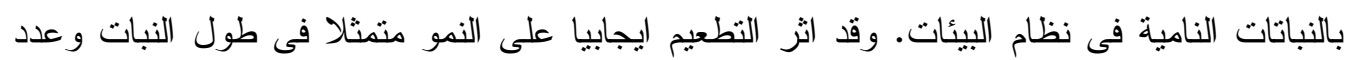

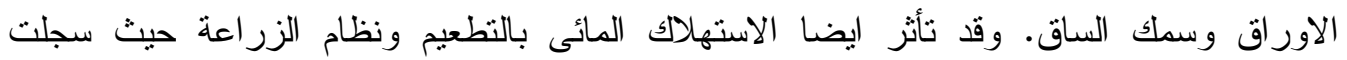

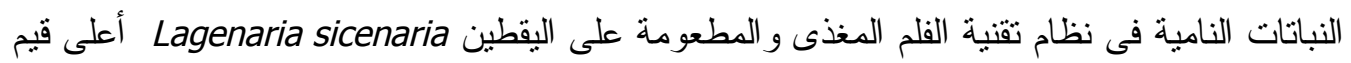

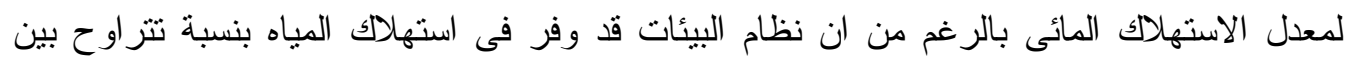
85-87\% عند مقارنته بالكميات المستهلكة والمحسوبة طبقا لحسابات الاستهالاك المائى بطريق البخر pan evaporation method. وقد لوحظ انخفاض المحصول نحت نظام زراعة البيئات

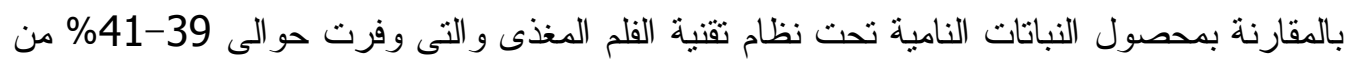

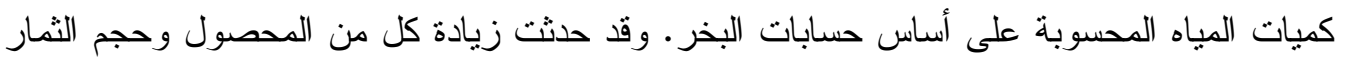

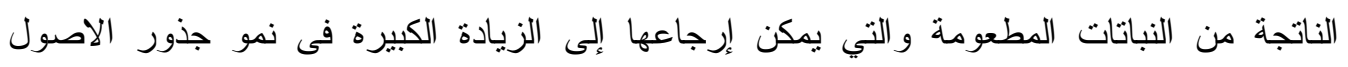

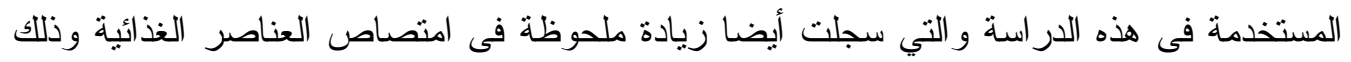

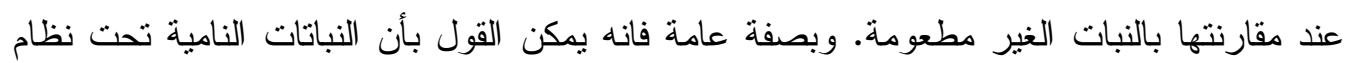
تقتنة الفلم المغذى قد أعطت أفضل جودة ومحصول وتنكير ومحتوى من العناصر .

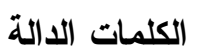
الكنتالوب - النطعيم - الاستهلاك المائي - تقنية الفلم المغذى - البيئات الزر اعية - الدحصول. 